\title{
PEWARISAN KEBERAGAMAN DAN KETELADANAN MELALUI SEJARAH LOKAL
}

\author{
Tutiek Ernawati \\ SMA Negeri 1 Balong Kab. Ponorogo
}

\begin{abstract}
Abstrak: Masjid Jami Tegalsari merupakan salah satu masjid kebanggaan masyarakat "Bhumi Reyog”. Masjid ini terletak di DesaTegalsari, Kecamatan Jetis, Kabupaten Ponorogo. Di kompleks masjid ini dahulu pernah didirikan pondok pesantren, yaitu Pondok Pesantren Gerbang Tinatar, karena terletak di desa Tegalsari, maka lebih dikenal sebagai Pondok Pesantren Tegalsari. Bukti kemasyhuran pondok pesantren ini masih dapat kita rasakan saat ini ketika mengunjungi Masjid Jami' Tegalsari. Pondok pesantren ini memiliki banyak santri dari berbagai daerah. Seorang pujangga Jawa yang masyhur Raden Ngabehi Ronggowarsito, tokoh pergerakan nasional H.O.S Cokroaminoto, Susuhunan Paku Buwana II, merupakan deretan alumni Pondok Pesantren di Tegalsari tersebut. Jejak Paku Buwono II di Tegalsari mencatat sejarah lokal di Ponorogo, dan menjadikan beragamnya sejarah di kota Ponorogo. Nilai-nilai keteladanan dan keberagaman dapat diwariskan melaui sejarah lokal Pondok Pesantren Tegalsari.
\end{abstract}

Kata Kunci: Tegalsari, Paku Buwono II, Kasan Beshari.

\begin{abstract}
Tegalsari Jami Mosque is a famous mousques in "the land of Reyog". This mosque is situated in Tegalsari village, Jetis distict, Ponorogo. In this mosque complex, there was an Islamic boarding school known as Pondok Pesantren Tegalsari. This boarding school has a lot of students from various regions. Many historical figures learned in this boarding school such as Raden Ngabehi Ronggowarsito (a famous Javanese man of letters), H.O.S. Cokromanitoto (a famous national movement figure), and Susuhunan Pakubuwana II (a Javanese king). Pakubuwana II's legacy was spread around Ponorogo, especially in Tegalsari, which shaped the local history of this city. There are various values that could be instil to the next generation through the local history of Pondok Pesantren Tegalsari.
\end{abstract}

Keywords: Tegalsari, Paku Buwono II, Kasan Beshari

Ponorogo adalah sebuah kabupaten kecil di wilayah Propinsi Jawa Timur. Secara tipografis wilayah Ponorogo terdiri dari dataran rendah dan pegunungan. Secara administratif, Kabupaten Ponorogo terdiri dari 21 kecamatan, yaitu Pudak, Pulung, Sooko, Ngebel, Sambit, Sawoo, Jenangan, Babadan, Siman, Mlarak, Jetis, Balong, Bungkal, Slahung, Ngrayun, Sukorejo, Kauman, Jambon, Badegan, Sampung, dan Ponorogo (Sugianto, 2015:8). Dalam tulisan ini penulis ingin sedikit mengungkap keberadaan situs di salah satu kecamatan, yaitu di kecamatan Jetis. Salah satu hal yang mendorong penulis memilih situs tersebut karena belum adanya tulisan khusus yang mengupas tentang jejak keberadaan Paku Buwono II di Ponorogo.

Di Ponorogo sebenarnya terdapat banyak situs sejarah. Di antara situs-situs tersebut banyak juga yang masih "tersembunyi" dari pandangan masyarakat. Dalam konteks ini, artinya masyarakat banyak yang masih belum mengetahui tentang situs-situs sejarah di daerahnya sendiri, baik itu tempat situsnya, maupun sejarah tentang keberadaan situs tersebut. Keberadaan situs-situs tersebut menjadi kekayaan sejarah lokal. Sejarah lokal memiliki peran penting dalam mempertahankan nilai-nilai budaya di dalam masyarakat. Masyarakat bisa mempelajari banyak hal dari sejarah lokal untuk kehidupan yang baik pada masyarakat tersebut. Melalui sejarah lokal, masyarakat dapat mengambil nilai-nilai yang terkandung di dalamnya.

Sejarah lokal adalah sejarah dari suatu tempat, suatu locality, yang batasannya ditentukan oleh penulis. Batasannya dapat berupa suatu tempat tinggal suku bangsa, suatu kota, atau bahkan suatu desa (Abdullah, 1978:15). Pentingnya sejarah lokal bagi masyarakat kurang didukung dengan kesadaran masyarakat itu sendiri akan pentingnya upaya pelestariannya. Hal itu salah satunya terlihat dari kurangnya penulisan tentang sejarah lokal. Penyampaian sejarah dari generasi 
ke generasi masih berupa tradisi lisan. Oleh karena itu, penulis ingin mencoba untuk menyampaikan sejarah lokal melalui tulisan.

Dalam tulisan ini penulis mengangkat salah satu situs sejarah di Desa Tegalsari Kecamatan Jetis Kabupaten Ponorogo, yaitu Situs Pesantren Gerbang Tinatar Tegalsari. Penulis akan membahas Susuhunan Paku Buwono II. Dalam hal ini Paku Buwono II merupakan pelaku sejarah. Lebih lanjut tulisan ini berusaha mengungkap nilai keteladanan Paku Buwono II selama nyantrik di Tegalsari.

\section{PONDOK PESANTREN GERBANG TINATAR/TEGALSARI}

Sejarah masuknya Islam di Indonesia berdasarkan penelitian para ahli sudah dimulai sejak abad ke-7 M. Pendapat para ahli sejarah tersebut tentunya didukung dengan adanya bukti-bukti yang kuat. Bukti-bukti tersebut ditemukan di banyak daerah yang sekaligus menjadi bukti penyebaran Islam di daerah tersebut. Misalnya, makam Siti Fatimah di desa Leran Gresik, makam Maulana Malik Ibrahim, masjid Agung Sumenep, dan sebagainya. Keberadaan bukti penyebaran Islam tersebut juga dimanfaatkan sebagai obyek wisata.

Jika di Gresik terdapat makam Siti Fatimah binti Maimun, makam Maulana Malik Ibrahim, Sunan Giri, dan sebagainya, di Ponorogo juga terdapat bukti-bukti penyebaran Islam, salah satunya adalah Masjid Jami Tegalsari. Secara administratif masjid tersebut terletak di Desa Tegalsari, kecamatan Jetis, yang berjarak sekitar sepuluh kilometer di sebelah timur kota Ponorogo. Masjid Jami Tegalsari merupakan peninggalan Kyai Ageng Mohamad Besari, yang masih keturunan Brawijaya V Raja Majapahit (Purwowijoyo, 1984:33). Kyai Mohamad Besari mendapatkan tanah Tegalsari dari Kyai Donopuro, seorang Kyai pengasuh Pondok Setono. Selanjutnya didirikanlah Masjid dan Pesantren Tegalsari pada abad ke-18. Masjid Jami’ Tegalsari menunjukkan ciri sebagai masjid kuno Indonesia, yang tampak dari bentuk atapnya yaitu atap tumpang. Atap tersebut merupakan atap sirap. Selain itu juga terdapat makam di belakang masjid ( masjid makam). Masjid yang berarsitektur Jawa ini memiliki 36 tiang dan atap berbentuk Kerucut.
Jumlah tiang mengandung arti jumlah wali songo $(3+6)$ dan atap berbentuk kerucut yang menggambarkan keagungan Allah SWT.

Masjid Tegalsari menyatu dengan Pondok Pesantren seluas $4500 \mathrm{~m}^{2}$. Pondok Pesantren Tegalsari awalnya bernama Pondok Pesantren Gerbang Tinatar, namun karena terletak di desa Tegalsari, maka kemudian lebih dikenal sebagai Pesantren Tegalsari. Pada masa jayanya, Pesantren Tegalsari merupakan pesantren besar dengan santri yang berjumlah ribuan. Kebesaran pesantren ini terkenal kemana-mana. Dari sumber sejarah (Kasdi, 2005:12) yang penulis peroleh, Pondok Pesantren Tegalsari memiliki banyak santri, baik dari lingkup sekitar Tegalsari maupun dari luar, bahkan dari luar daerah Ponorogo. Di antara santri-santri dari luar tlatah Ponorogo yaitu Bagus Burhan (Rongowarsito), DAN Paku Buwono II.

Pesantren tersebut sekarang sudah tidak ada bekasnya, namun keberadaannya mengukir sejarah perkembangan Islam di Ponorogo. Kejayaan pesantren Tegalsari dilanjutkan oleh pondok pesantren-pondok pesantren besar yang hingga sekarang masih ada, di antaranya Pondok Gontor dan Pondok Termas Pacitan.

\section{PAKU BUWONO II DI PONDOK PESANTREN GERBANG TINATAR TEGALSARI}

Kedatangan Paku Buwono II ke wilayah Ponorogo dikarenakan terdesak dalam menghadapi pemberontakan Raden Mas Garendi di keratonnya, yaitu Kartasura pada tahun 1742 . Serangan yang dilakukan pemberontak sangatlah hebat, sehingga Paku Buwana II dan pasukannya kalah telak. Raden Mas Garendi menjadi raja Surakarta dengan nama Sunan Kuning (Purwowijoyo, 1985:21). Setelah mengalami kekalahan, Paku Buwana II beserta pengikutnya pergi meninggalkan kraton menuju timur Gunung Lawu dan akhirnya sampailah mereka di Ponorogo. Ada beberapa tempat yang menjadi petilasannya, dahulu tempat-tempat tersebut merupakan tempat pertapaan beliau di Ponorogo. Tempat yang dimaksud antara lain Desa Pulung di gunung Selayon, Desa Mangkujayan, Desa 
Sawoo, dan DesaTegalsari. Di tempat yang disebut terakhir, di tengah kekhawatiran dan ketakutannya, beliau bertemu Kyai Kasan Beshari. Beliau kemudian mondok dan nyantri di Tegalsari.

Di pondok pesantren Kyai Kasan Beshari di Tegalsari tersebut, Paku Buwana II ditempa oleh Sang Kyai. Paku Buwono II diajari untuk menyerahkan diri sepenuhnya kepada Allah SWT. Beliau digembleng untuk bertafakur dan bermunajat hanya kepada Allah SWT. Di tempat ini Paku Buwono II mendapat tambahan ilmu keagamaan Islam dengan baik. Semua ajaran yang diberikan oleh Sang Kyai diikutinya dengan sungguh-sungguh. Kyai Besari juga senantiasa mendoakan agar Susuhunan Paku Buwono II diberi kekuatan oleh Sang Pencipta untuk tetap dapat memimpin Kartasura.

Setelah sekian waktu nyantri di Pondok Tegalsari, Paku Buwono II kembali ke Kartasura. Sinuwun Paku Buwana II kembali ke Kartasura diikuti beberapa santri terpilih, dengan pemuka santri Bagus Harun Basyariah yang merupakan keturunan orang terhormat, yaitu Ki Ageng Prongkot di Tosanan, Sumoroto (daerah bagian barat kabupaten Ponorogo) (Purwowijoyo, 1985:25). Ketika perjalanannya sampai di barat daerah Sumoroto, hari sudah malam, beliau dan rombongan memutuskan singgah di rumah penduduk, yaitu di rumah Mbok Rondo Punuk. Rombongan Paku Buwono II diterima dengan senang hati, kemudian Mbok Rondo menyuguh tamunya dengan jenang katul (bubur dari sari kulit padi). Paku Buwono memakan jenang tersebut langsung dari tengah, melihat hal itu mbok rondo Punuk mengingatkan "wong mangan jenang kok saka tengah, iku salah. Yen perang ya kalah!rak ya saka pinggir, saya nengah saya adhem. Iku nek peranga ya menang." (Makan jenang mengapa dari tengah, itu salah. Kalau perang jadi kalah. Seharusnya dari pinggir, ke tengah sudah dingin. Kalau perang akan menang) (Purwowijoyo, 1985:25). Paku Buwana II kemudian mengikuti perkataan Mbok Rondo Punuk, makan jenang dari pinggir. Perkataan Mbok Rondo Punuk inilah yang nantinya akan diterapkan Paku Buwana II ketika menghadapi Sunan Kuning, pemberontak ditaklukkan dari pinggiran kota.
Setelah menginap di rumah Mbok Rondo Punuk, rombongan Paku Buwana II mengucapkan terima kasih, dan berpamitan melanjutkan perjalanan kembali ke Kartasura. Paku Buwana II berpesan agar Mbok Rondo Punuk datang ke keraton Kartasura. "Nanti kalau ada waktu, kelak engkau datanglah ke Kartosuro, ini engkau saya beri surat, adapun tanda-tanda rumahku, kalau ada rumah yang mempunyai halaman lebar, yaitu rumahku". Di lain waktu Mbok Rondo kemudian datang menghadap ke Kartosuro dan dianugerahi Bumi Merdiko (perdikan) sampai sekarang (Purnomo, 1985:16).

Keuletan dan kesungguhan Paku Buwana II selama di pesantren dalam beribadah, dan keikhlasan Kyai Ageng dalam memberikan seluruh ilmunya, Allah SWT mengabulkan doa-doa Paku Buwana II. Akhirnya beliau beserta pengikutnya berhasil memukul mundur pasukan pemberontak dari Kraton Mataram. Sebagai balas budi, Sunan Paku Buwana II mengangkat Kyai Kasan Beshari sebagai menantunya. Sejak saat itu Tegalsari menjadi desa "Perdikan", yaitu desa istimewa yang bebas dari segala kewajiban membayar pajak kepada kerajaan.

Bagaimana dengan mbok rondo Punuk? Suatu hari Mbok Rondo Punuk datang menghadap ke keraton Kartasura bersama keponakaannya. Kedatangannya disambut baik oleh Paku Buwana II dan istri beliau. Paku Buwana kemudian memberikan hadiah kepada Mbok Rondo Punuk dandang botol, berupa harta benda dan piagam. Isi piagam tersebut menyebutkan bahwa Mbok Rondo Punuk beserta keturunannya menjadi lurah di desanya, dan desa tersebut menjadi desa perdikan. Desa tersebut bernama desa Menang (terletak di sebelah barat kecamatan Kauman, Sumoroto). Desa Menang menjadi wilayah kecamatan Badengan sekarang).

Keberadaan Paku Buwana II di Ponorogo, meskipun tidak lama, tetapi telah membuat catatan dalam perjalanan sejarah Kabupaten Ponorogo, terutama konstelasi masa kesultanan Islam, sehingga menjadikan sejarah Ponorogo lebih beragam.

\section{NILAI-NILAI KETELADANAN}


Nilai adalah sesuatu yang diyakini sebagai hal yang baik, benar, dan bahkan menjadi panutan, baik secara individu maupun oleh kelompok masyarakat. Dari sejarah lokal, ada nilainilai keteladanan yang dapat kita warisi, menjadi contoh dan dapat kita implementasikan dalam kehidupan sehari-hari sebagai individu dan masyarakat. Demikian juga dengan sejarah Susuhunan Paku Buwono II. Meskipun keberadaan beliau tidak lama di Ponorogo, namun jejaknya telah mewarnai ragam sejarah lokal kota reyog tersebut, dan memberikan nilai keteladanan yang patut kita contoh. Nilai-nilai keteladanan yang dimaksud diantaranya adalah percaya pada kuasa Tuhan, bahwa sebagai manusia beriman harus senantiasa berdoa, berserah diri kepada Tuhan, dan meyakini kebesaranNya. Kesungguhan dan kerja keras, bahwa dengan dua hal tersebut, tujuan yang ingin dicapai InsyaAllah akan terwujud. Hal yang diajarkan oleh Mbok rondo Punuk kepada Susuhunan Paku Buwono II tentang tata cara makan (dari pinggir ke tengah), selain untuk kesopanan (adab), menurut penulis hal itu juga mengandung nilai filosofi yang baik (hendaknya kita mengerjakan sesuatu dengan cara yang benar, maka akan kita dapatkan suatu keberhasilan). Ada juga nilai keteladanan yang tidak kalah pentingnya yang telah Susuhunan Paku Buwono II contohkan, yaitu balas budi atas kebaikan yang telah diberikan orang lain. Hal itu dilakukan oleh beliau terhadap Mbok Rondo Punuk, yaitu pemberian hadiah berupa harta dan tanah perdikan untuk Desa Menang, dan pemberian kekuasaan (sebagai lurah di Desa Menang kepada Mbok Rondo Punuk dan keturunannya).

Tentu banyak nilai keteladanan yang dapat kita warisi dari beragam sejarah lokal. Mari kita kenal sejarah lokal di sekitar kita. Sejarah local memperkaya sejarah nasional, dan sarat nilai keteladanan yang dapat kita warisi, untuk kita implementasikan dalam kehidupan sehari-hari.

\section{PENUTUP}

Pada masa lalu Pondok Pesantren Tegalsari memiliki banyak santri, baik dari lingkup sekitar Tegalsari maupun dari luar, bahkan dari luar daerah Ponorogo. Di antara santri-santri dari luar tlatah Ponorogo yaitu Bagus Burhan (Rongowarsito), Paku Buwono II. Di pondok pesantren Kyai Kasan Beshari di Tegalsari tersebut, Paku Buwana II ditempa oleh Sang Kyai. Paku Buwono II diajari untuk menyerahkan diri sepenuhnya kepada Allah SWT dan digembleng untuk bertafakur dan bermunajat hanya kepada Allah SWT.

Setelah sekian waktu nyantri di Pondok Tegalsari, Paku Buwono II kembali ke Kartasura. Sinuwun Paku Buwana II kembali ke Kartasura dengan diikuti beberapa santri terpilih dengan pemuka santri Bagus Harun Basyariah yang merupakan keturunan orang terhormat, yaitu Kyai Ageng Prongkot di Tosanan Sumoroto (daerah bagian barat kabupaten Ponorogo).

Sebagai balas budi, Sunan Paku Buwana II mengangkat Kyai Kasan Beshari sebagai menantunya. Sejak saat itu Tegalsari menjadi desa "Perdikan", yaitu desa istimewa yang bebas dari segala kewajiban membayar pajak kepada kerajaan.

Keberadaan Paku Buwana II di Ponorogo (Pondok Gerbang Tinatar Tegalsari), meskipun tidak lama, tetapi telah membuat catatan dalam perjalanan sejarah Kabupaten Ponorogo, terutama pada masa perkembangan Islam, sehingga menjadikan sejarah Ponorogo lebih beragam. Jejaknya juga memberikan nilai keteladanan yang patut kita contoh. Di antaranya adalah percaya pada kuasa Tuhan, kesungguhan dan kerja keras, sopan santun, balas budi dan nilai filosofi tentang cara mengerjakan sesuatu yang benar.

\section{RUJUKAN}

Abdullah, T. 1978. Sejarah Lokal di Indonesia. Yogyakarta: Gadjah Mada University Press

Kasdi, A. 2005. Memahami Sejarah. Surabaya: Unesa University Press.

Kuntowijoyo. 2013. Pengantar Ilmu Sejarah. Yogyakarta : Tiara Wacana.

Poernomo, M. 1985. Sejarah Kyai Ageng Mohammad Besari. Jakarta : H.U..S. Danu Subroto.

Poesponegoro, Marwati Djoened. 2010. Sejarah Nasional Indonesia, Jilid III. Jakarta: Balai Pustaka 
Purwowijoyo. 1985. Babad Ponorogo Jilid III. Ponorogo: Dinas Pariwisata Dan Seni Budaya Pemerintah Kabupaten Ponorogo. 1985. Babad Ponorogo Jilid $V$. Ponorogo: Dinas Pariwisata
Dan Seni Budaya Pemerintah Kabupaten Ponorogo.

Sugianto, A. 2015. Eksotika Pariwisata Ponorogo. Yogyakarta: Samudra Biru. 